\title{
Microbiological Quality of a Locally Brewed Alcoholic Beverage (Pito) Sold in a Community within the Greater Accra Region, Ghana
}

\author{
Andrew A. Minamor ${ }^{1}$, Alberta L. Mensah ${ }^{1}$, Emmanuel Nii Laryea ${ }^{1}$, Emmanuel Afutu $^{1}$ \\ and Patience B. Tetteh-Quarcoo ${ }^{2, *}$
}

1 Department of Science Laboratory Technology, Accra Technical University, Accra, Ghana

2 Department of Medical Microbiology, School of Biomedical and Allied Health Sciences, University of Ghana, Accra, Ghana

* Correspondence should be addressed to Patience B. Tetteh-Quarcoo: patborket2002@yahoo.com / pbtetteh-quarcoo@ug.edu.gh

Andrew A. Minamor: minamorandrew@yahoo.com

Alberta Mensah Larteley: albyluv003@gmail.com

Emmanuel Nii Laryea: Sylvalary@yahoo.com

Emmanuel Afutu: emmalineafutu@yahoo.com

Patience B. Tetteh-Quarcoo: patborket2002@yahoo.com / pbtetteh-quarcoo@ug.edu.gh

\section{Abstract}

Pito is a traditionally brewed alcoholic beverage in some African countries. It is gaining much prominence, and the patronage among the youth is noteworthy. Therefore, samples of the drink were collected every week for six weeks from three different popular brewing sites at Lower Prampram in the Ningo-Prampram District of Accra, Ghana. The samples were processed and examined for bacteria and fungi using the Standard Plate Count (SPC) technique. A total of six different bacteria and a fungus were isolated. The bacteria were Escherichia coli, Klesiella pneumoniae, Shigella spp, Enterobacter aerogenes, Staphylococcus aureus and Pseudomonas aeroginosa, whiles the fungus was Saccharomyces cerevisiae. Total viable counts as well as individual isolates counts in all the pito samples were found to be less than $10^{4} \mathrm{cfu} / \mathrm{ml}$. It is noteworthy that, Saccharomyces cerevisiae, the only fungus isolated is known to be associated with fermentation and the microbes isolated from the pito samples were found to be within the permissible limits. However, these potentially pathogenic microbes, if found in unacceptable limits, from the fermenting samples could merit public health attention. Therefore, periodic screening of pito and their brewers, coupled with education on the maintenance of recommended guidelines concerning food and drink production is encouraged.

Keywords: pito; beverage; bacteria; coliform; Lower Prampram; Ghana

\section{Introduction}

Pito is a traditionally brewed alcoholic beverage. It is produced mainly from the grains of guinea corn (Sorghum vulgare or Sorghum bicolor) and millet [1]. Pito brewing originally started in the northern part of Ghana but its production is now widely spread over the entire country, serving as a lucrative business particularly for the rural folks. It is produced traditionally by malting, mashing, fermentation and maturation of the grains which are steeped 
in water over night, after which excess water is drained. The grains are then placed in layers and germinated with periodic moistening. Germination continues for four to five days until the plumule attains a length of about $2.5 \mathrm{~cm}$ or longer [2]. The malted grains are spread out in the sun to dry for one to two days after which the dried malt is milled into powder. Boiling of the wort is done among other reasons, to denature malt enzymes and enzymes supplements [2-4]. Pito is golden yellow to dark brown in colour, with taste varying from slightly sweet to sour. It has been observed that, pure cultures of microorganism can be used to reduced fermentation time and improve production process of the pito [5]. Such pure cultures include Lactobacillus plantarum in combination with Saccharomyces cerevisiae and Pediococcus halophilus in combination with Candida tropicalis [5]. The $\mathrm{pH}$, colour, titrable acidity, alcohol content, specific gravity, taste and flavour of 'Pito' produced by use of pure culture can be compared favourably with that produced using the traditional method [5]. In Ghana, about four types of pito can be identified depending on their wort extraction and fermentation methods. These include the Nandom, Kokomba, Togo, and Dagarti Pito [6]. Compared with European beers, pito is heavier and darker, but less bitter. It is also lighter in colour and thinner in consistency than European stout beer [7]. It is mostly neither bottled nor canned [8], but purchased directly from the household in which it is brewed. It is typically served in a calabash or bottle outside the producer's home where benches are provided for the consumers to sit on and enjoy their beverage. Meanwhile, it has been observed that this beverage can be processed, bottled and stored for 2 months with little or no effect on its characteristics and qualities [9]. Nevertheless, fresh samples of pito have been accepted as better than the stored ones in terms of both microbiological and nutritional quality $[10,11]$. Pito is usually consumed as a nutritious beverage to quench hunger and thirst. It has social and economic significance, particularly to the people of the three northern regions of Ghana [7]. It is used for the performance of certain traditional functions such as pouring of libations at social gatherings, funerals, marriage and child-naming ceremonies. While pito seems to serve as refreshment during leisure hours and constitutes a source of income for the producers in the rural areas, when overused intoxicates and could lead to violence as well as indecent behavior as sometimes observed, especially in such large gathering. In addition, all the health risks commonly associated with overconsumption of alcoholic beverages [12] also apply to the misuse of pito. Similar to other openly sold foods and drinks, several factors may make pito prone to microbial contaminations. Potential microbes that can contaminate pito may include bacteria such as E. coli, Salmonella species, Shigella species and Staphylococcus aureus [13], whiles fungal contaminants may include Aspergillus flavus, Aspergillus niger and Saccharomyces cerevisiae [14-16]. Meanwhile, Saccharomyces cerevisiae is known to be associated with fermentation $[14,15$, 17]. A microbiological and physico-chemical analysis of a traditional sorghum beer "Ikigage", collected from the southern province of Rwanda showed the presence of microbes such as aerobic mesophilic bacteria, lactic acid bacteria, E. coli, feacal streptococci, Staphylococcus aureus, yeast, and moulds [18]. Other contaminant can also be associated with such locally produced beverages. For example, in a small market survey, aflatoxin B1 was detected to be associated with a beverage 'Horchata' derived from tiger nuts frequently consumed in Southern Europe [19]. Similarly, aflatoxins were detected in all the samples of traditional opaque sweet beverage (thobwa) and beer prepared from sorghum malts, collected from the southern region of Malawi and analyzed [20]. In that study, the average aflatoxin content in the beer was found 
to be higher than the permissible maximum level expected to be detected in a ready to eat foods [20]. In most parts of Africa, the passion for drinking outweighs other considerations such as safety of the drinks and beverages, leading to considerable rise in drink-borne intoxications and contamination [21]. A good search through pertinent literature revealed that, not much work has been done to ascertain the microbial quality of pito brewed at Lower Prampram in the Ningo-Prampram district of Ghana, where pito brewing is gaining much prominence and the patronage of the drink is very high among the youth. This study therefore, sought to provide information on the microbial quality and safety of this beverage by isolating and identifying microorganisms in pito produced and sold within this community.

\section{Materials and Methods}

\subsection{Study site \& sample collection}

This was a cross sectional study. Three different sites at Lower Prampram in the NingoPrampram district of Accra, Ghana, where pito brewing is gaining much prominence were selected for the current study. The sites were Prampram Keba shoo, Prampram Alata and Prampram Abia. Pito samples were bought from consented vendors at the three different sites for a period of six (6) weeks (Spanning from March to mid-April). Within the first 2 weeks, pito samples were bought from ten (10) vendors at one site, after which the samples were prepared and examined at the laboratory. Subsequently, the same process was repeated for the two other sites in the second and third 2 weeks. Prior to the purchase of the samples, verbal interviews and brief discussions were held with the vendors to have an idea of the condition of the places where the pito was brewed and when it was prepared. An observation was also made on how the pito was handled during the selling process. The samples were put in clean, autoclave-sterilized bottles and transported on ice packs to the Microbiology Laboratory of the Department of Science Laboratory Technology, Accra Technical University, from where clearance was obtained, for examination and analysis.

\subsection{Serial Dilution of Pito samples}

Stock solutions of the various samples were prepared by pipetting $10 \mathrm{ml}$ each into three sterilized bottles filled with $90 \mathrm{ml}$ peptone water. To prepare the diluents, $15 \mathrm{~g}$ of peptone powder was dissolved into $1000 \mathrm{ml}$ sterile distilled water, boiled on a hot-plate for peptone to dissolve completely; then sterilized in an autoclave at a temperature of $121^{\circ} \mathrm{C}$ for 15 minutes. Exactly $9 \mathrm{ml}$ of the peptone water was pipetted into each of 9 sterilized test-tubes. A $1 \mathrm{ml}$ aliquot of stock sample A was aseptically transferred into one of the nine (9) test-tubes containing 9ml of the peptone solution and mixed thoroughly using whirl shaker to form $10^{-1}$ dilution. One milliliter $(1 \mathrm{ml})$ of the $10^{-1}$ dilution was aseptically transferred after homogenization into the second test tube containing $9 \mathrm{ml}$ of the peptone solution to form $10^{-2}$. Similarly, $10^{-3}$ dilution was prepared for sample A, so that each sample utilized three sterile test-tubes. This procedure 
was repeated for stock samples B and C. The samples were serially diluted to reduce the concentration of cells to more usable concentration in order to obtain more manageable results.

\subsection{Culturing, enumeration and Isolation of bacteria and fungi}

The conventional Pour Plate method [22] was used in culturing, enumeration and isolation of bacteria and fungi. Briefly, the samples were well mixed and using a micropipette with disposable tips, one milliliter $(1 \mathrm{ml})$ aliquot of each diluted sample was pipetted into the center of appropriately labeled empty petri dish. About $15 \mathrm{~mL}$ of $45^{\circ} \mathrm{C}$ molten medium was poured into the inoculated petri dish. Media used were Plate Count Agar, Xylose-LysineDesoxycholate Agar, Cystine Lactose Electrolyte Deficient (CLED) Agar, Eosin Methylene Blue (EMB) agar and Dichloran Rose Bengal Chloramphenicol (DRBC) agar. The media and sample in the petri dish were mix thoroughly by tilting and swirling the dish whiles carefully watching out not to slop the agar over the edge of the petri dish. The agar was then allowed (for about 10 minutes) to completely gel without disturbing it, after which the plate was incubated. Three (3) replicates were prepared for each dilution. All the media and media ingredients such as peptone used in the study were from Scharlau, Spain and Sigma Chemical Co. Ltd., USA. Total viable bacterial count was performed on Plate Count Agar (LAB 149). Xylose-Lysine-Desoxycholate Agar (XLD) was used for isolation and enumeration of Klebsiella pneumoniae, Enterobacter aerogenes and Shigella spp., Eosin Methylene Blue (EMB) agar for total coliform and Escherichia coli. Cystine Lactose Electrolyte Deficient (CLED) Agar was used for Staphylococcus aureus and Pseudomonas aeruginosa and Dichloran Rose Bengal Chloramphenicol (DRBC) was used for fungal isolation. Petri plates for bacteria were incubated at $37^{\circ} \mathrm{C}$ for $24-48$ hours whilst fungal plates were incubated at $28^{\circ} \mathrm{C}$ for 5 days. The colonies seen based on colonial morphology such as colour, shape, size and consistency were counted using a colony counter (Stuart Scientific, UK), and recorded as colony forming unit per millilitre $(\mathrm{cfu} / \mathrm{ml})$. Bacterial colonies were further sub-cultured onto fresh Agar plates using a sterile loop ( $2 \mathrm{~mm}$ inside diameter) to obtain pure cultures for further identification. Similarly, fungal colonies were sub-cultured onto fresh Dichloran Rose Bengal Chloramphenicol (DRBC) Agar to obtain pure culture for further identification (Figure 1). The plates containing DRBC for fungal isolation were incubated in the inverted position. This method of incubation completely obviated the usually sprinkling of powdery spores of Penicillium and Aspergillus species on plates incubated in the upright position [23].

\subsection{Identification of isolates}

Bacterial identification was done based on a number of procedures including microscopy, Gram staining, oxidation-fermentation tests and a battery of biochemical tests such as urease test, catalase test, citrate utilization test, indole test and triple sugar iron test [24-26]. Fungal identification was done using the fungi conventional identification manual [27]. 


\section{Results}

Six bacteria namely: Staphylococcus aureus, Escherichia coli, Enterobacter aerogenes, Pseudomonas aeruginosa, Shigella spp. and Klebsiella pneumoniae were isolated from all the eighteen (18) samples collected from the three sampling points. Saccharomyces cerevisiae was the only fungus isolated (Figure 1).

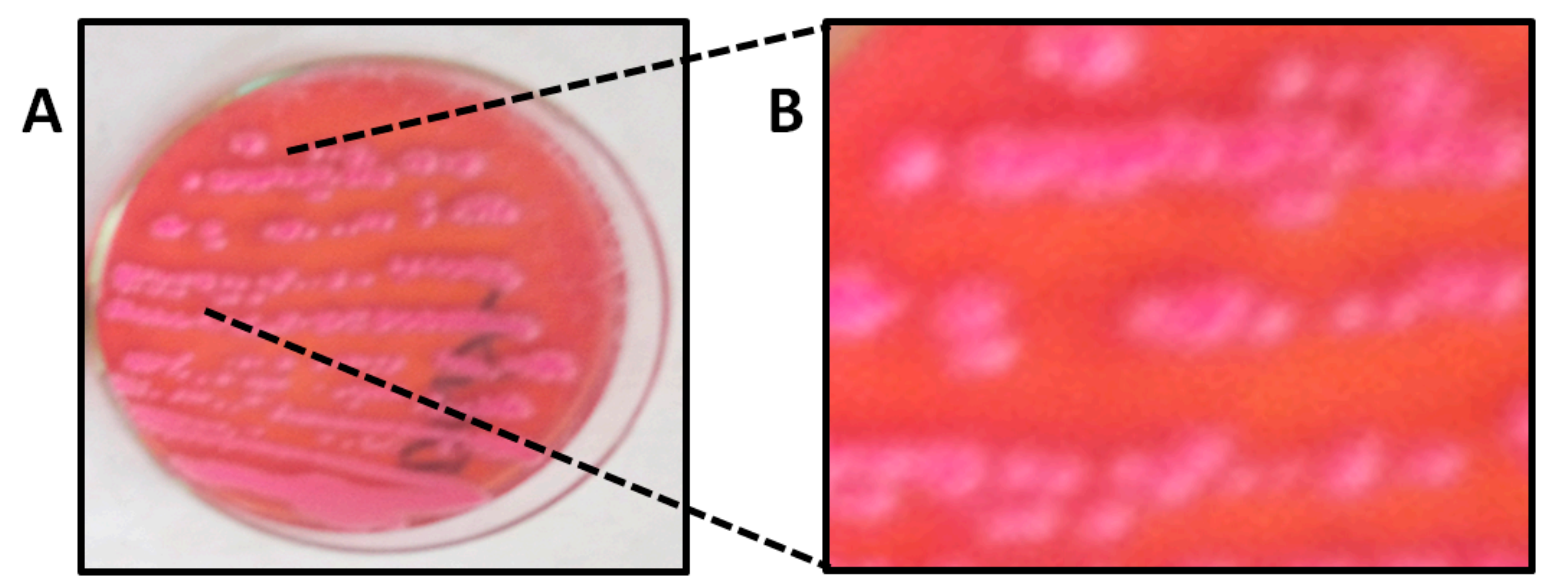

Figure 1. Saccharomyces cerevisiae colonies on DRBC agar. (a) Pink and reduced size pure colonies (b) Zoom in of single colonies picked for further identification

All the bacterial and fungal isolates were present at each of the sampling locations (Table 1). The isolates occurred in varied percentages in the samples from each of the sampling points (Table 1). Saccharomyces cerevisiae and Staphylococcus aureus were the highest occurring microbes isolated at Prampram Keba shoo (22.2\%) whiles Pseudomonas aeruginosa was the highest (25.0\%) among the isolates at Prampram Alata (Table 1). At Pampram Alata, again, Saccharomyces cerevisiae and Enterobacter aerogenes both showed the highest occurrence (22.2 \%). Meanwhile, Klebsiella pneumoniae was the least occurring isolate from Prampram Keba Shoo (3.7\%), while Klebsiella pneumoniae exhibited the least occurrence from Pampram Alata (7.1\%). Shigella spp and Escherichia coli both showed the least occurrence $(7.4 \%)$ at Prampram Abia (Table 1).

Table 1. Number and percentage occurrence of bacteria and fungus isolated from the Pito samples.

\begin{tabular}{lll}
\hline Sampling sites & Microorganisms & $\mathbf{n}(\mathbf{\%})$ \\
\hline Prampram Keba Shoo (N=27) & Staphylococcus aureus & $6(22.2 \%)$ \\
& Escherichia coli & $4(14.8)$ \\
& Enterobacter aerogenes & $3(11.11 \%)$ \\
& Pseudomonas aeruginosa & $4(14.8 \%)$ \\
& Shigella spp. & $3(11.1 \%)$ \\
& Klebsiella pneumoniae & $1(3.7 \%)$ \\
& Saccharomyces cerevisiae & $6(22.2 \%))$ \\
Pampram Alata (N=28) & Staphylococcus aureus & $5(17.9 \%)$
\end{tabular}




\begin{tabular}{|c|c|c|}
\hline & Escherichia coli & $3(10.7 \%)$ \\
\hline & Enterobacter aerogenes & $3(10.7 \%)$ \\
\hline & Pseudomonas aeruginosa & $7(25.0 \%)$ \\
\hline & Shigella spp. & $3(10.7 \%)$ \\
\hline & Klebsiella pneumoniae & $2(7.1 \%)$ \\
\hline & Saccharomyces cerevisiae & $5(17.9 \%)$ \\
\hline \multirow[t]{7}{*}{ Prampram Abia $(\mathrm{N}=27)$} & Staphylococcus aureus & $4(14.8 \%)$ \\
\hline & Escherichia coli & $2(7.4 \%)$ \\
\hline & Enterobacter aerogenes & $6(22.2 \%)$ \\
\hline & Pseudomonas aeruginosa & $4(14.8 \%)$ \\
\hline & Shigella spp. & $2(7.4 \%)$ \\
\hline & Klebsiella pneumoniae & $3(11.1 \%)$ \\
\hline & Saccharomyces cerevisiae & $6(22.2 \%)$ \\
\hline
\end{tabular}

$\mathrm{N}$ represents the total number of microbes at a particular site. $\mathrm{n}$ represents number of particular isolate identified.

Occurrence ranges of the bacteria from the sampling sites were between $3.7 \%-22.2 \%$ for Prampram Keba Shoo, 7.4\% - 22.2\% for Prampram Abia and 7.1\% - 25.0\% for Pampram Alata. Overall, $S$. cerevisiae recorded the highest percentage occurrence among all the microbes isolated with a mean value of $20.8 \%$ followed by Staphylococcus aureus with a mean value of $18.3 \%$. The least mean percentage occurrence $(7.3 \%)$ was recorded by Klebsiella pneumoniae (Figure 2).

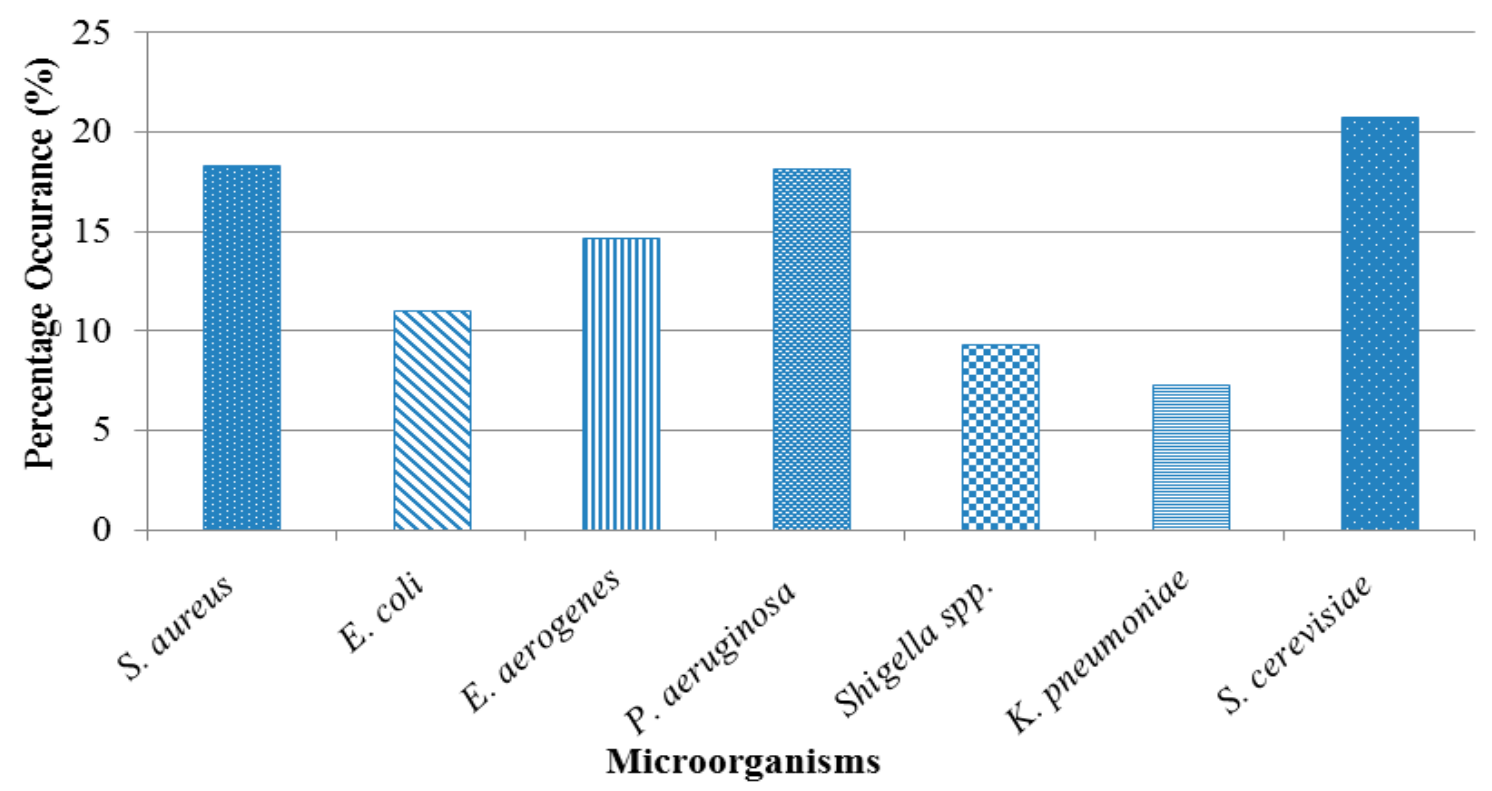

Figure 2. Mean percentage occurrence of the bacteria and fungus isolated

The microbes isolated in all the pito samples were found to be within counts of less than $10^{4}$ $\mathrm{CFU} / \mathrm{ml}$. The colony counts of different isolates from the various samples sites for the 6 weeks are as follows: Total viable bacteria $\left(3.2 \times 10^{3}-5.4 \times 10^{3}\right)$, Total Coliform $\left(1.4 \times 10^{2}-4.6 \mathrm{x}\right.$ $\left.10^{2}\right)$, Escherichia coli $\left(1.6 \times 10^{2}-2.3 \times 10^{2}\right)$, Staphylococcus aureus $\left(2.5 \times 10^{2}-3.7 \times 10^{2}\right)$, 
Shigella spp. $\left(1.7 \times 10^{2}-2.2 \times 10^{2}\right)$, Klebsiella pneumoniae $\left(1.1 \times 10^{2}-1.4 \times 10^{2}\right)$, Enterobacter aerogenes $\left(1.5 \times 10^{2}-2.8 \times 10^{2}\right)$, Pseudomonas aeruginosa $\left(1.1 \times 10^{2}-1.4 \times 10^{2}\right)$ and Saccharomyces cerevisiae count $\left(2.9 \times 10^{2}-3.5 \times 10^{2}\right)$ [Table 2]. Thus the Pito drinks analyzed were found to be within the permissible limits of acceptable microbiological quality [20].

Table 2. Mean Colony Count (CFU/ml) of isolates in pito samples from various sample sites

\section{Location}

\begin{tabular}{lccc}
\cline { 2 - 4 } Isolates & Prampram Keba Shoo & Prampram Alata & Prampram Abia \\
\hline Bacteria & $2.3 \times 10^{2}$ & $1.8 \times 10^{2}$ & $1.6 \times 10^{2}$ \\
E. coli & $3.7 \times 10^{2}$ & $3.1 \times 10^{2}$ & $2.5 \times 10^{2}$ \\
S. aureus & $2.1 \times 10^{2}$ & $2.2 \times 10^{2}$ & $1.7 \times 10^{2}$ \\
Shigella spp. & $1.1 \times 10^{2}$ & $1.4 \times 10^{2}$ & $1.9 \times 10^{2}$ \\
K. pneumoniae & $1.9 \times 10^{2}$ & $1.5 \times 10^{2}$ & $2 . .8 \times 10^{2}$ \\
E. aerogenes & $2.1 \times 10^{2}$ & $3.8 \times 10^{2}$ & $2.4 \times 10^{2}$ \\
$P$. aeruginosa & $1.4 \times 10^{2}$ & $3.2 \times 10^{2}$ & $4.2 \times 10^{2}$ \\
Total coliform & $5.4 \times 10^{3}$ & $3.3 \times 10^{3}$ & $3.2 \times 10^{3}$ \\
Total viable bacteria & & & \\
Fungus & $3.5 \times 10^{2}$ & $2.9 \times 10^{2}$ & $3.2 \times 10^{2}$ \\
S. cerevisiae & &
\end{tabular}

\section{Discussion}

Indigenous foods and drinks such as beverages form part of the culture of human society. While pito seems to serves as refreshment and constitutes a source of economic return for the alcoholic beverage producers in the rural areas, it has not always been possible to have absolute control over the processing of indigenous foods and drinks, particularly in developing countries. This may be due to varied reasons, including inadequate knowledge of food processing and handling practices by processors and vendors. An investigation on pito samples from four cities in Ghana led to the detection of the presence of toxic metal such as $\mathrm{Na}, \mathrm{K}, \mathrm{Fe}$, $\mathrm{Cu}$, and $\mathrm{Zn}$, although in acceptable levels [8]. However, the study recorded high levels above the permissible limit of toxic metals such as $\mathrm{Ni}, \mathrm{Pb}$, and $\mathrm{Cd}$ in the samples. The study attributed the presence of the toxic metal in the pito sample to poor handling and primitive equipment used in the production process but not from the grains (sorghum) since not all the sample investigated contained the toxic metals [8]. In another study which looked at the nutritional composition and microbial analysis of pito, it was found that, in addition to essential mineral elements such as calcium, magnesium and iron, the pito samples also contained microorganisms such as Staphylococcus aureus, Escherichia coli, Bacillus subtilis, Streptococcus species, Proteus species, Rhizopus stolonifer, Aspergillus flavus, Aspergillus niger, Saccharomyces cerevisiae and Mucor species [1]. The presence of these microorganisms was also attributed to poor handling during production. Similar isolates were found in varying percentage occurrence from the three sampling points in the current study. This emphasizes the close association of these organisms to pito. Even though, the microbes isolated from the samples were found to be within acceptable limits of microbiological quality [28], the isolates 
are potentially pathogenic and therefore if found above the limits, could attract public health attention.

In the present study Saccharomyces cerevisiae was the only fungus isolated and had the highest mean percentage of occurrence (20.8\%) than all the bacterial isolates. This observation is not surprising since this fungus is known to be involved in fermentation [14, 15, 17] and could therefore have been implicated in the fermentation of the pito. Apart from Saccharomyces cerevisiae, the bacterial isolates from the pito samples can be considered microbial contaminants even though the quantities were within the acceptable limits. In a similar study, lactic acid bacteria isolates were found to be involved in the various production stages of Pito [29]. Staphylococcus aureus is a normal flora of the skin, and the common ethological agent of septic arthritis [30]. Its presence in the sample may be attributed to poor handling during production, packaging and selling. Escherichia coli is a very important member of the coliform group. It is part of the normal flora of the intestine of human and vertebrates. In spite of this, some strains of $E$. coli can cause gastroenteritis, urinary tract infection [31] as well as diarrhoea in infant [32]. Therefore, identification of this bacterium in the pito samples could merit public health attention. In a related study, which reported the presence of coliforms in hawked KununZaki drink (A sorghum based but non-alcoholic beverage) widely consumed in Nigeria, the presence of the coliforms was attributed to the use of contaminated water, containers, as well as unhygienic environment where the drinks were processed and even hawked [33]. Similar factors could account for the presence of the coliforms in the pito samples examined. Pseudomonas aeruginosa which was isolated in all the pito samples in this study is ubiquitous, mostly saprophytic, commonly found in water, soil or other moist environments [34]. It is an opportunistic pathogen and can cause urinary tract infections, respiratory system infections, and gastrointestinal infections, among others [35]. The presence of this organism in the pito samples might be due to the use of ordinary (unsterilized) water in the dilution of the finished pito before serving and drinking. Klebsiella pneumoniae found in the pito samples is widely distributed in nature, occurring both as commensals in the intestines and as saprophytes in soil and water. It has become a very important cause of nosocomial infections [34]. It causes pneumonia, urinary infection, other pyogenic infections, septicemia, meningitis and rarely diarrhoea. Some strains of K. pneumoniae have been shown to produce an enterotoxin [34], therefore pito consumers could be at risk of suffering from health problems associated with the enterotoxin, if such strains were to have been isolated. Enterobacter aerogenes also found in this study can cause urinary tract infections and hospital-acquired infections. They are widely distributed in humans and animals, as well as in water, sewage, and soil. Since asymptomatic carriers had been associated with Shigella spp [36], their presence can be attributed to both contaminated water and such asymptomatic carriers, who might be working in the brew house $[37,38]$. Unhygienic way of serving this local alcoholic beverage, coupled with poor storage, makes the pito drink attract flies that pitch on it and sometimes even fall into it. Therefore, another possible route of transmission could be by insects such as house flies, fruit flies [39] and cockroaches [40] that may reside in and around the brew house. 


\section{Conclusion}

The current study demonstrated the presence of different bacteria, as well as Saccharomyces cerevisiae in the pito samples. Even though potentially pathogenic microbes were isolated, the colony forming units were within the permissible limits for microbiological quality. However, these microbes, when found in unacceptable quantities in the fermenting samples, could raise public health concern. Therefore, it is recommended that, authorities who regulate food and drink production, maintain their routine education on safety of food and drinks for the pito handlers. This is to further reduce microbial contamination, while periodically screening locally-produced beverages and their producers.

\section{Abbreviations}

S. aureus: Staphylococcus aureus, E. coli : Escherichia coli, P. aeruginosa : Pseudomonas aeruginosa, E. aerogenes: Enterobacter aerogenes, K. pneumoniae : Klebsiella pneumoniae, S. cerevisiae : Saccharomyces cerevisiae, XLD : Xylose-Lysine-Desoxycholate, EMB: Eosin Methylene Blue, CLED: Cystine Lactose Electrolyte Deficient, DRBC: Dichloran Rose Bengal Chloramphenicol, WHO: World Health Organization, F.A.O: Food and Agricultural Organization. Ni: Nickel, Pb: Lead, Cd: Cadmium, Na: Sodium , K: Potassium , Fe: Iron, Cu: Copper, Zn: Zinc.

\section{Acknowledgements}

The authors wish to acknowledge all pito sellers who participated in the study. We wish to thank all the staff of the Departments of Sciences Laboratory Technology, Accra Technical University, especially the laboratory assistants at the Microbiology Laboratory.

\section{Author contributions}

AAM conceived and designed the experiments: AAM, ALM, and EA participated in collection and analyses of the data. AAM, ALM, EA and PBT-Q participated in drafting of the manuscript. AAM, ENL, and PBT-Q contributed in interpretation of the data. PBT-Q and E.A jointly developed the structure and arguments for the manuscript. AAM, ENL, and PBT-Q made critical revisions and approved final version. All authors read and approved the final manuscript.

\section{Conflicts of interest}


The authors declare that they have no competing interests.

\section{References}

1. Kolawole, O.M.; Kayode, R.M.O; Akinduyo, B. Proximate and microbial analyses of brukutu and pito produced in IIorin, Nigeria. African Journal of Biotechnology. 2007, 5, 587590.

2. Shemilt, L.W. Chemistry and World Food Supplies: The New Frontiers, Chemrawn II. Editor L.W. Shemilt. IUPAC. Chemical Research Applied to world needs. Pergamon Press. 1983

3. Dicko, M.H.; Gruppen, H.; Traore, A.S.; Voragen, A.G J.; van Berkel, W.J.H. Sorghum grain as human food in Africa: relevance of content of starch and amylase activities. Afr. $J$. Biotechnol. 2006, 5 (5), 384-395.

4. Kayodé, A.P.P.; Hounhouigana, J.D.; Nout, M.J.R. Impact of brewing process operations on phyta, phenolic compounds and in vitro solubility of iron and zinc in opaque sorghum beer," LWT, 2007a, 40, 834-841.

5. Orji, M.U.; Mbata, T.I.; Anich, G.N.; Ahonkhai, I. The use of starter cultures to produce "pito", a Nigerian fermented alcoholic beverage. World J. Microbiol. Biotechnol. 2003, 19, 733-736.

6. Sefa-Dedeh, S.; Sanni, A.I.; Tetteh, G.; Sakyi-Dawson, E. Yeasts in the traditional brewing of pito in Ghana. World Journal of Microbiology and Biotechnology. 1999, 15, 593597.

7. Ekundayo, J.A. The production of pito, a Nigerian fermented beverage. Journal of Food Technology. 1969, 4, 217-225.

8. Duodu, G.O.; Amartey, E.O.; Asumadu-Sakyi, A.B.; Adjei, C.A.; Quashie, F.K.; NsiahAkoto, I.; et al., Mineral profile of pito from Accra, Tamale, Bolgatanga, and WA in Ghana. Food and Public Health. 2012, 2 (1) 1-5. doi: 10.5923/j.fph.20120201.01.

9. Ellis, W.O.; Oduro, I.; Terkuu, D.M. Preliminary studies on extension of the shelf life of pito. Journal of Science and Technology. 2005, 25 (1) 11-15.

10. Fadahunsi, I. F.; Ogunbanwo, ST.; Fawole, A.O. Microbiological and nutritional assessment of burukutu and pito (indigenously fermented alcoholic beverages in West Africa) during storage. Nat Sci. 2013. 11, (4) 98-103.

11. Sanni, A.I.; Onilude, A.A.; Fadahusi, I.F.; Afolabi, R.O. Microbial deterioration of traditional alcoholic beverages in Nigeria. Food Res. Int. 1999, 32, 163-167. 
12. Zhou, Y.; Zheng, J.; Li, S.; Zhou, T.; Zhang, P.; Li, H.B. Alcoholic Beverage Consumption and Chronic Diseases. Int J Environ Res Public Health, 2016. 13 (6), E522.

13. Umaru, G.A.; Tukur, I. S.; Akensire, U. A.; Adamu, Z.; Bello, O. A.; Shawulu, A H. B.; et al, Microflora of Kunun-Zaki and Sobo drinks in relation to public health in Jalingo Metropolis, NorthEastern Nigeria. Int. J. Food Res. 2014, 1, 16-21.

14. Clavijo, A.; Calderón, I.L.; Paneque, P. Yeast assessment during alcoholic fermentation inoculated with a natural "pied de cuve" or a commercial yeast strain. World J Microbiol Biotechnol. 2011. 27, 1569.

15. van der Aa Kühle, A.; Jesperen, L.; Glover, R.L.; Diawara, B.; Jakobsen, M. Identification and characterization of Saccharomyces cerevisiae strains isolated from West African sorghum beer. Yeast. 2001.18, 1069-1079.

16. Sanni, A.I.; Lonner, C. Identification of yeast isolated from Nigerian traditional alcoholic beverages. Food Microbiology.1993, 10, 517- 523.

17. N'guessan, F.K.; N'diri, D.Y.; Camara, F.; Djè, M.K. Saccharomyces cerevisiae and Candida tropicalis as starter cultures for the alcoholic fermentation of tchapalo, a traditional sorghum beer. World J. Microbiol. Biotechnol. 2010, 26, 693-699.

18. Lyumugabe, L.; Kamaliza, G.; Bajyana, E.; Thonart, Ph. Microbiological and physicochemical characteristics of Rwandese traditional beer "Ikigage". Afr. J. Biotechnol. 2010, 9, 4241-4246.

19. Arranz, I;. Stroka, J.; Neugebauer, M. Determination of aflatoxin B1 in tiger nut-based soft drinks. Food Addit Contam. 2006. 23 (3), 305-308.

20. Matumba, L.; Monjerezi, M.; Khonga, E.B.; Lakudzala, D.D. Aflatoxins in sorghum, sorghum malt and traditional opaque beer in southern Malawi. Food Control. 2011, 22, 266268.

21. Miller, J.D. Mycotoxins. In: Cardwell KF, editor. Proceedings of the workshop on mycotoxins in food in Africa; Cotonou, Benin. International Institute of Tropical Agriculture, 1996, 18-22.

22. Maturin, L. J.; Peeler, J. T. “Aerobic plate count," in Bacteriological Analytical Manual, chapter 3, United states Food and Drug Administration (US FDA), 2001, http://www.fda.gov/Food/FoodScienceResearch/

23. Minamor, A.A. Influence of the metabolites of three Paecilomyces species on the germination and seedling development of two Ghanaian maize (Zea Mays L) varieties 
(Abeleehi and Obaatanpa). International Journal of Engineering Research \& Technology, 2013, 2(6), 2013.

24. Ryan, K.J.; Ray, C.G.; editors. Sherris Medical Microbiology, 4th edition, New York: 333 McGraw Hill, 2004.

25] Harrigan. W.F. Laboratory Methods in Food Microbiology. (3rd ed.) Academic Press. San Diego, 1998, 198.

26. MacFaddin, J. F. Biochemical Tests for Identification of Medical Bacteria. Baltimore, MD: Lippincott Williams and Wilkins, 2000.

27. Samson, R.A.; Van Reenen-Hoekstra, E. Introduction to food-borne fungi, 3rd Edition, Centraal bureau Voor Schimmel Culture Baar. Institute of the Royal Netherlands Academy of Arts and Sciences, 1988.

28. Foodstandards. Guidelines for the microbiological examination of ready-to-eat foods. Australia New Zealand. Available at http://www.foodstandards.gov.au/code/microbiollimits/Pages/default.aspx . Accessed August 6, 2016.

29. Sawadogo-Lingani, H.; Lei, V.; Diawara, B.; Nielsen, D.S.; Møller, P.L.; Traoré, AS.; Jakobsen, M. The biodiversity of predominant lactic acid bacteria in dolo and pito wort, for production of sorghum beer. J. Appl. Microbiol. 2007, 103, 765-777.

30. Uriarte, M.; Egües, C.A.; Errazquin, N.; Meneses, C.F.; Hernando, I.; Belzunegui, J. THU0256 Septic Arthritis: Retrospective Case Series. Ann Rheum Dis. 2015, 74, 289-290, doi:10.1136/annrheumdis-2015-eular.5090

31. Sivick, K. E.; Mobley, H. L. T. Waging War against Uropathogenic Escherichia coli: Winning Back the Urinary Tract. Infect. Immun. 2010, 78(2) 568-585.

32. Nataro, J.P.; Kaper, J.B. Diarrheagenic Escherichia coli. Clin. Microbiol. Rev, 1998, 11(1), 142-201.

33. Amusa, N.A.; Ashaye, O.A. Effect of processing on nutrition, microbiological and sensory properties of Kunun-Zaki (A sorghum based non-alcoholic beverage) widely consumed in Nigeria. Pakistan Journal of Nutrition. 2009, 8, 288-292.

34. Green, S.K.; Schroth, M.N.; Cho, J.J.; Kominos, S.K.; Vitanza-jack, V.B. Agricultural plants and soil as a reservoir for Pseudomonas aeruginosa. Appl Microbiol, 1974, 28, 987991.

35. Driscoll, J.A.; Brody,; S.L.; Kollef, M.H. The epidemiology,pathogenesisandtreat- ment of Pseudomonasaeruginosa infections. Drugs. 2007, 67, 351-368. 
36. Qadri, M.H.; AI-Gamdi, M.A.; Al-Harfi, R.A. Asymptomatic Salmonella, Shigella and Intestinal Parasites Among Primary School Children in the Eastern Province, Journal of Family \& Community Medicine. 1995, 2(2), 36-40.

37. Dunn, R. A.; Altamirano, J. V.; Dietrich, S. E.; Hall, W. N.; Johnson, D. R.; RobinsonDunn, B. Outbreak of Shigella flexneri linked to salad prepared at a central commissary in Michigan. Public Health Rep. 1995. 110, 580-586.

38. Todd, E.C.; Greig, J.D.; Bartleson, C.A.; Michaels, B.S. Outbreaks Where Food Workers Have Been Implicated in the Spread of Foodborne Disease. Part 3. Factors Contributing to Outbreaks and Description of Outbreak Categories. Journal of Food Protection. 2007, 70 (9), 2199-2217.

39. Barreiro, C.; Albano, H. Silva, J.; Teixeira, P. Role of Flies as Vectors of Foodborne Pathogens in Rural Areas. ISRN Microbiology, 2013, 718780. doi:10.1155/2013/718780.

40 Tetteh-Quarcoo, P.B.; Donkor, E.S.; Attah, S.K.; Duedu, K.O.; Afutu, E.; Boamah, I. et al., Microbial carriage of cockroaches at tertiary care hospital in Ghana. Environmental Health Insights. 2013, 7, 59-66, doi: 10.4137/EHI.S12820.

(C) 2017 by the authors; licensee Preprints, Basel, Switzerland. This article is an open access article distributed under the terms and conditions of the Creative Commons by Attribution (CC-BY) license (http://creativecommons.org/licenses/by/4.0/). 